Araştırma Makalesi / Research Article

\title{
AKILLI KENTLER VE YAŞAM LABORATUVARLARI (LIVING LABS): BAŞAKŞEHİR YAŞAM LABORATUVARI ÖRNEĞİNDE BİR İNCELEME**
}

\author{
Dr. Öğr. Üyesi Levent MEMIŞ** (D) \\ Giresun Üniversitesi, İ̈BF, Giresun (levent_memis@hotmail.com) \\ Hülya KÜÇÜK BAYRAKTAR (1) \\ İstanbul Üniversitesi, SBF, İstanbul (hulya_364@hotmail.com)
}

\begin{abstract}
ÖZET
Çalışmanın konusunu yaşam laboratuvarlarının (YL) bir örneğini teşkil eden Başakşehir Yaşam Laboratuvarı (BYL) oluşturmaktadır. BYL, örnek olay araştırma tasarımı kapsamında, genel düzeyde yapı ve işleyiş olarak incelenmektedir. Araştırmanın genel sonuçlarına göre, BYL'nin oluşumu, güçlü başkan modelinin etkisi altında Başakşehir Belediye Başkanı'nın girişimiyle 2011 yılında kurulumu gerçekleşmiş ve 2014 yılında aktif faaliyete geçmiştir. BYL'nin bütçesi Başakşehir Belediyesi (BB) tarafindan karşılanmakta ve yönetimi, özel sektöre ylllı olarak verilmektedir. BYL'nin sunduğu imkânlar, fiziksel ortamdaki çalışmaları öne çıkarmakta ve çeşitli çabaların sergilendiği görülmektedir. Diğer taraftan BYL'nin bulunduğu yerleşim alanının dışına da (il içi ve il dışı) yansımaları olduğu görülmektedir. Ayrıca bu iş birliği süreçlerinde eğitim kurumlarının varlı̆̆ dikkat çekmektedir. Sonuç olarak BYL, bazı sorun alanlarını barındırmakla birlikte, örnek bir uygulamaya karşılık gelmektedir.
\end{abstract}

Anahtar Kelimeler: Akıllı Kent, Yaşam Laboratuvarı, Yenilik, Başakşehir.

\section{SMART CITIES AND LIVING LABS: AN INVESTIGATION ON THE SAMPLE OF BAŞAKŞEHIR LIVING LAB}

\begin{abstract}
Başakşehir Living Lab (BLL), which is an example of LL's, is the subject of our study. BLL is examined as a structure and operation at the general level within the scope of case study research design. According to the general results of the study, the formation of BLL was carried out in 2011 under the influence of the strong chairman model and in the initiative of the Mayor of Bassaksehir. Then, it became active in 2014. The budget of BLL is covered by MM (Metropolitan Municipality) and its management is given annually to the private sector. The opportunities offered by BLL are highlighted in the physical environment, and it is seen that various efforts are being demonstrated. On the other hand, it is observed that there are also reflections outside the BLL settlement area (in and out of the city). In addition, the presence of educational institutions in these cooperation processes is noteworthy. As a result, BLL corresponds to an exemplary embodiment while hosting some problem areas.
\end{abstract}

Keywords: Smart City, Living Lab, Innovation, Başaksehir.

\footnotetext{
* Bu çalışma, Yerel Kalkınma ve Siyasal-Toplumsal Dönüşüm Bă̆laminda Kent ve Çevre Yönetimi Forumu (III. Kentfor, 7-9 Eylül 2018, Karaman)'nda aynı başlık altında sözlü olarak sunulmuş ve özet kitapçığında yer almış bildiri metninin genişletilmiş halinden oluşmaktadır.

** Sorumlu yazar.
} 


\section{Giriş}

Kent yaşamının dinamik yapısı ve kendine has özellikleri, hazır kalıpların ötesinde, karşılaşılan duruma yönelik çözüm önerilerini önemli kılmaktadır.Bu süreç, karşılaşılan sorun ve ihtiyaçların tespit edilmesinden başlamakta, çözüm geliştirmeyle devam etmekte ve uygulamaya aktarılmasıyla son bulmaktadır. Bu noktada sorun ve ihtiyaçların tespitinde bilhassa, kentin günlük yaşam pratiği içinde yer alanların varlığı önemli olmaktadır. Yine çözüm önerilerinin geliştirilmesi ve uygulamaya aktarılması sürecinde, kurumsal düzeyde tarafların varlığı önem kazanmaktadır. Bu arada sorunlara çözüm üretme açısından teknoloji önemli potansiyelleri barındırmaktadır. İfade edilenler bağlamında kentsel yaşamda karşılaşılan sorun ve ihtiyaçlara çözüm geliştirme ve uygulama sürecinde, farklı tarafları bir araya getiren, YL'ler öne çıkmaktadır. Fen ve sağlık bilimleri gibi alanlarda, olguların incelenmesinde olmazsa olmaz bir araç olarak yer alan laboratuvarlar, sosyal bilimler açısından yeni bir durumdur. YL'ler, sosyal bir olguyu gerçek yaşam şartlarında inceleyerek çözümler üretmek ve üretilen çözümleri hayata geçirme çabasıdır.

Sosyal alanda laboratuvarların, belirli süreli veya herhangi bir süre sınırı olmadan ortaya çıktığı ve çalışmalarını sürdürdüğü anlaşılmaktadır (Nesti, 2017: 7; Brask, 2015: 30-31; Menny, 2016: 21; Menny vd., 2018: 70). YL'lerin karşılık bulduğu önemli sosyal alanlardan biri de kentlerdir (Westerlund vd., 2018: 44). Kent yaşam laboratuvarı [Urban LivingLab (ULL)] (Marvin vd., 2018: 1; Menny, 2016; Baccarne vd., 2014b) veya ekolojik kent yaşam laboratuvarı (ecocitylivinglab) (Lin vd., 2012) gibi kavramlarla nitelendirilmektedir. Kentsel YL'lerin ortaya çıkışı genel olarak; kentsel sürdürülebilirlik, kentsel alanda karşılaşılan zorluklar ve ilgi gruplarının ve paydaşların dahil olması durumlarına dayandırılmaktadır (Marvin vd., 2018: 5).

YL'ler, gerçek yaşam şartlarında uygulamalar yaparak, öngörülemeyen ve karmaşık durumlara yönelik çözüm geliştirmede etkisini göstermektedir. YL'ler, teknoloji odaklı yeniliklerin gelişmesine imkân sağladığı gibi (Folstad, 2008: 116), genel düzeyde de sosyal yeniliklerin ortaya çıkmasına imkân sağlamaktadır (Smas vd., 2016: 920). Fakat daha çok Bilişim ve İletişim Teknolojisi (BİT)'nin gelişimi ve sosyal alanlara yansımasıyla YL'lerin gelişim gösterdiği anlaşılmaktadır (Menny, 2016: 5). Gerçekleştirilen bir literatür incelemesinde akıllı kent (smart city) kavramına, YL'lerle ilgili makalelerin başlık ve anahtar kavramlar kısmında en fazla tekrarlanan kavram olarak yer verildiği tespit edilmektedir (McLoughlin vd., 2018). Bu bağlamda akıllı uygulamalar ile ön plana çıkan kentlerde, sorunların/ihtiyaçların tespit edilmesi ve çözüm üretilmesi amacıyla farklı tarafların bir araya geldiği YL'ler öne çıkmaktadır (Bifulco vd., 2017: 29). 1990'ların sonu ve 2000'li yılların başında ortaya çıkan YL'ler (Herselman vd., 2010: 2), akıllı kentlerde, açık bir yenilik eko-sistemi olarak farklı tarafların bir araya geldiği ve yeniliklerin üretildiği bir platform işlevi görmektedir. Dünya genelinde farklı sektörlerden aktörlerin öncülüğünde, farklı odak konu alanlarında faaliyetlerini yürüten 400'ün üzerinde YL'lerin olduğu bilinmektedir. Ayrıca bir üst oluşum olarak laboratuvarlar ağı [ENoLL (European Network of LivingLabs)] da bulunmaktadır.

$\mathrm{Bu}$ çalışmada YL olgusu, kentte karşılaşılan sorunlara yeni teknolojiler bağlamında çözüme aracı olan bir platform olarak ele alınmaktadır. Araştırmanın kapsamını 2014 yılında aktif faaliyete geçen BYL oluşturmaktadır. Türkiye'de bulunan dört YL'den biri olan BYL, aynı zamanda ENoLL üyesidir. Örnek olay araştırma tasarımına dayanan bu çalışmanın 
temel amacı, Başakşehir Belediyesi girişimiyle, kentin sorunlarına teknoloji odaklı çözümler üretmek amacıyla ortaya çıkan BYL'yi oluşum, yapı ve işleyiş açısından incelemektir. Bu bağlamda temel düzeyde şu soruların cevabı aranmaktadır: 1. Laboratuvarın ortaya çıkışını ve devamlılı̆̆ını să̆layan etmenler nelerdir?, 2. Laboratuvar, yapısal ve işleyiş açısından nasıl özelliklere sahiptir?, 3. Laboratuvar, farklı taraflarla nasıl bir iş birliği örüntüsü ortaya çıkarmaktadır?, 4. Ortalama dört yıllık zaman sürecinde laboratuvarın kent açısından kazanımları hangi noktalarda ortaya çıkmaktadır? İfade edilen soruların cevabı için, mülakat ve doküman incelemesi yöntemi kullanılmaktadır. Bu araştırmayla, BYL deneyimi üzerinden elde edilen bulgularla yaşam laboratuvarları öne çıkarılarak, ilgili literatüre ve benzer oluşumların diğer kentlerde de karşılık bulmasına katkı sağlanması beklenmektedir.

\section{Akıllı Kentlerin Bir Fonksiyonu Olarak Yaşam Laboratuvarları}

Gelişen yeni teknolojiler, kentlerin karşılaştığı sorunların ve ihtiyaçların giderilmesinde önemli fırsatları barındırmaktadır. Teknoloji tabanlı uygulamaların kentin farklı alanlarında karşılığını bulmasıyla ortaya çıkan yeni durum, daha çok akıllı kent kavramı ile nitelendirilmektedir.

Akıllı kentlerin oluşturulma sürecinde, yukarıdan aşağıya ve aşağıdan yukarıya olmak üzere iki yaklaşım öne çıkmaktadır. Birinci yaklaşımda akıllı uygulamaların öncülüğünü daha çok şirketler yürütmekte, bu noktada merkezileşmiş bir durum söz konusu olmaktadır. İkinci yaklaşımda ise, yereldeki aktörleri sürece dahil ederek uygulama geliştirmeye önem verilmektedir (Coenen vd., 2014: 3). Burada önemli olan, akıllı kentlere yönelik politika geliştirme sürecinde kullanıcı odaklılığı da kapsayan ikinci yaklaşımın önem kazanmasıdır (Dameri, 2013: 2545; Baccarne vd., 2014b). Bunun için de politika süreçlerinde farklı tarafların katkı sağladığı "açık yenilik" anlayışına ihtiyaç duyulmaktadır. Açık yenilik, akıllı kentlerin ayrılmaz önemli bir parçasıdır. Tam da bu noktada açık yeniliği sağlayan bir platform olarak YL'ler karşılığını bulmaktadır (Paskaleva, 2011: 165-167).

YL'lere yönelik ortak bir tanım bulunmamaktadır. Yapılan tanımlar odaklanılan alana göre farklılaşmaktadır. Bir tanım verecek olursak, ENOLL (https://enoll.org/about-us/) YL'yi, araştırma ve yenilik süreçlerini gerçek yaşama entegre eden, birlikte üretme yaklaşımına dayalı, kullanıcı odaklı açık inovasyon eko-sitemi olarak tanımlamaktadır.YL, güncel araştırma tasarımlarında, özellikle de inovasyon odaklı teknolojik merkezli araştırmalar kapsamında önemli bir araç haline gelmiştir. YL'ler, kentsel yaşam kalitesini sağlamak ve arttırmak için sınırlı kaynakların sürdürülebilir kullanımını geliştirmeyi amaçlamaktadır (Franz, 2015: 53).

YL'lerin ortaya çıkışında farklı taraflar etkili olmakla birlikte (Menny, 2016: 21; Kviselius vd., t.y. : 843; Rodrigues \& Franco, 2018: 782), bu aktörler arasında genel olarak devletin (Schuurman, 2015: 213) özelde de belediyelerin ve üniversitelerin öne çıtı̆̆ görülmektedir (bkz. Scholl \& Kemp, 2016: 91; Curtis, 2015: 15; Baccarne vd., 2014b; Nesti, 2017: 4; Gasco, 2017: 91). Diğer bir ifadeyle YL'lerin oluşumunda kamu aktörü öne çıkmakla birlikte, farklı tarafları kapsayıcı bir özelliği bulunmakta ve çalışma odağına göre farklı paydaşlar yer alabilmektedir (Schuurman, 2015: 225; Schuurman vd., 2013: 32).

YL'lerin en temel özelliklerinden biri farklı tarafları barındıran yönetişim yapısıdır (Brask, 2015: 30-31). YL'lerin işleyiş sürecinde, farklı taraflar, farklı kazanımlar elde edebilmektedir. YL'lerin bu kazan-kazan durumu farklı tarafları bir araya getirmekte ve 
taraflar arası ağların oluşmasına katkı sağlamaktadır (Rodrigues \& Franco, 2018: 783-784). $\mathrm{Bu}$ bağlamda imkân sağlayanlar (öncülük edenler), destekçiler (eğitim kurumları gibi), yararlananlar (firmalar ve yerel hizmet sağyacıları gibi) ve kullanıcılar (kentliler), YL'lerde yer almaktadır (Juujarvi \& Pesso, 2013: 27). Bu noktada örneğin öğrenciler ve eğitimciler, gerçek yaşam şartlarında yaparak öğrenme fırsatı bulmaktadır (Juujarvi \& Pesso, 2013: 26). Ifade edilen yapısıyla YL'ler; kullanıcılar, büyük şirketler, tedarikçiler, üniversiteler, küçük ve orta ölçekli işletmeler ve devlet kuruluşları gibi farklı yenilik paydaşları arasında arabulucu rolü oynamaktadır (Stahlbröst, 2013: 38; Sharp \& Salter, 2017: 2). Yer verilen özellikleriyle YL'lerin; ă̆ (Rodrigues \& Franco, 2018), ortam (Canzler vd.,2017: 25), açık yenilik merkezi (Gasco, 2017: 92), organizasyon gibi farklı biçimlerde konumlandırıldığı anlaşılmaktadır.

Diğer taraftan YL'lerin örgütlenmesi ve yönetimi açısından da farklı uygulamaların olduğu, bu anlamda hibrit bir yapıyı barındırdığı anlaşılmaktadır (Scholl \& Kemp, 2016: 97). YL'ler, belediyenin bir departmanı biçiminde örgütlendiği gibi, belediyenin dışında farklı aktörlerle iş birliği içinde yönetiminin gerçekleştiği yapılar da bulunmaktadır (Nesti, 2017: 10).

İfade edilenler kapsamında, YL'lerin bünyesinde birlikte üretim (co-creation), biçimsel ve biçimsel olmayan uygulamalarıyla, YL işleyişinin farklı aşamalarında (ürün/hizmet geliştirme, sunma, değerlendirme gibi, (Nesti, 2017: 10; Menny, 2016: 46-47; Menny vd., 2018: 72), farklı şekilde ve farklı boyutlarda (pasif, reaktif ve co-creatin, Mengual vd., 2018: 304) gerçekleşebilmekte ve birlikte üretmenin motivasyon ve teşviklerin değişkenlik göstermekte olduğu bilinmektedir (Puerari vd., 2018: 10). Burada özellikle vatandaşların ihtiyaçlarının öncelikle dikkate alınması önemli olmaktadır (Nesti, 2017: 7). Birlikte üretim mantı̆̆ı, YL üzerinden belediye örgütlenmesi içinde yer alan farklı birimler arasında da gerçekleşmektedir (Scholl\&Kemp, 2016: 96).

Uygulamalar incelendiğinde YL'lerin odak konuları (ulaşım, enerji, kentin geleceği, kentin problemleri gibi Menny, 2016: 21; Menny vd., 2018: 70; Canzler vd., 2017, multimedya, e-sağlık, evde bakım ve oyun, akıllı kent, akıllı enerji gibi, Schuurman, 2015: 254; öğrenciler, öğretmenler ve aileleri dikkate alan eğitim çalışmaları, Gasco, 2017: 94) farklılaşmaktadır. Bazen de YL'lerin uygulamanın dışında öğrenme ve araştırma amacıyla da faaliyetlerini yürüttüğü görülmektedir (Puerari vd., 2018: 9).

İlgili literatür incelendiğinde, YL'lerle ilgili araştırmalarda diğer konuların yanında akıllı kent, öne çıkan bağlamlardan birine karşılık gelmektedir (Westerlund vd., 2018: 44; 47; Cardullo vd., 2018; Cosgrave vd., 2013; Stahlbröst vd., 2015). Dolayısıyla akıllı kentlerin inşası sürecinde YL'lerin önemli işlevleri yerine getirdiği görülmektedir (Bifulco vd., 2017: 29).Akıllı kentler açısından YL'ler;BİT, nesnelerin interneti, sensörler, yapay zekâ, sanal gerçeklik, 3D gibi teknoloji odaklı akıllı yaşama yönelik yeniliklerin geliştirilmesinde ağırlık kazanmaktadır (Lin vd., 2012). Ayrıca adı geçen teknolojiler üzerinden ortaya çıkan büyük veri, sorunların/ ihtiyaçların tespitinde ve çözümlerin geliştirilmesinde yeni imkânlar sunabilmektedir.

Kentsel konularla ilişkilendirilerek gündeme gelen laboratuvarlar; sokak labı (Street Lab) (Casciola, 2016), kentsel yaşam labı (Steen \& Bueren, 2017)/kent labı (Scholl \& Kemp, 2016: 90) gibi farklı kavramlarla da nitelendirilmektedir. Kentsel alanda gündeme gelen labların temelde; kentsel sorunlara yenilikçi çözümler üretme, proje fikirleri geliştirme, vizyon belirleme, sürdürülebilir kalkınmayı destekleme, kentsel alanda karşılaşılan zorlukların 
üstesinden gelme, yeni aktörler ile karşılaşma gibi amaçlarının olduğunun altı çizilmektedir (Steen \& Bueren, 2017: 11; Marvin vd., 2018: 5; Scholl \& Kemp, 2016: 90). Ayrica genel olarak bakıldığında BİT'ler, YL'lerin ortak noktasını oluşturmaktadır (Angelini vd., 2016).

Aşağıda yer verilen Şekil 1'de kentsel ihtiyaçlar, teknolojik imkânlar ve YL arasında ilişkiye yer verilmektedir. Burada YL, teknolojinin sunduğu imkânlardan yararlanarak kentin sorun ve ihtiyaçlarını giderme aracı bir ortam olarak konumlandırılmaktadır. Öncesinde de belirtildiği üzere teknolojik imkânlar, YL'lerin önemli bir unsuru olmaktadır.

\section{Şekil 1: Kentsel İhtiyaçlar, Akıllı Kentler ve YL İlişkisi}

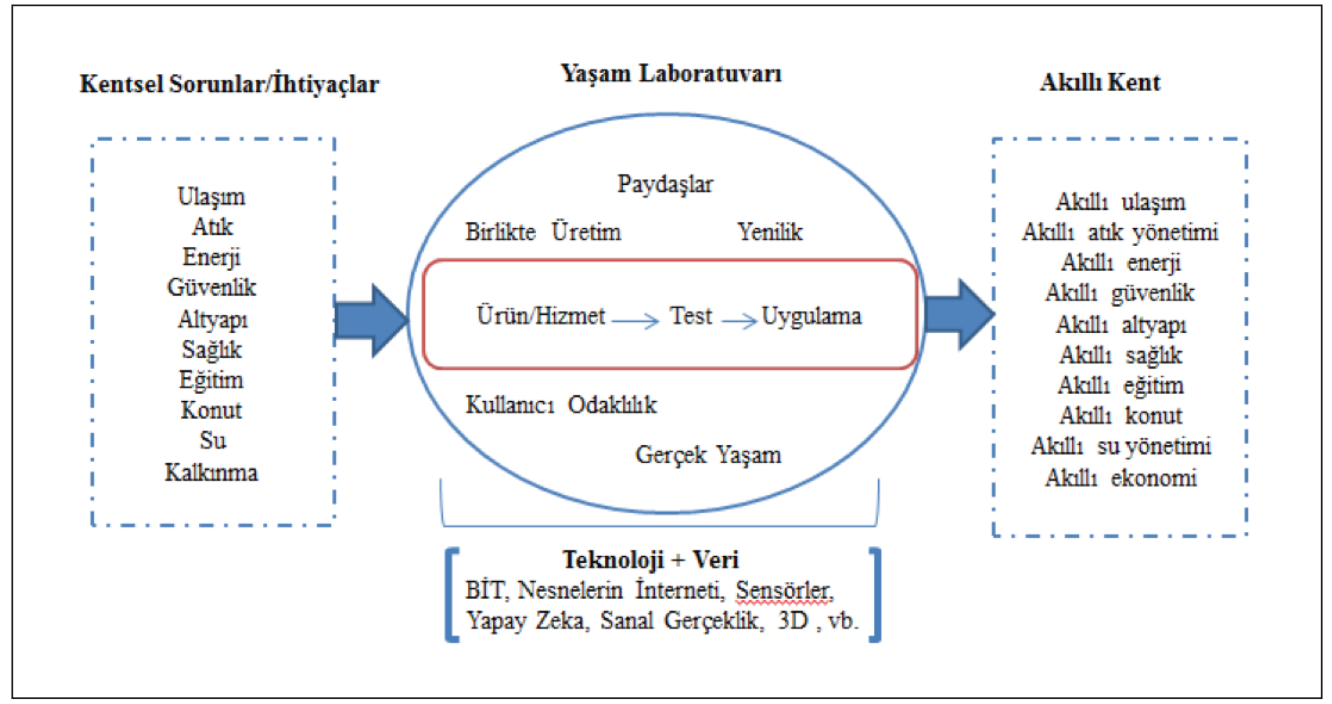

Kaynak: Yazarlar tarafından oluşturulmuştur.

Şekil 1'de görüldüğü üzere YL'lerin beş temel unsuru, ilgili literatürde öne çıkmaktadır. Bu unsurlar farklı biçimlerde sınıflandırılmakta olup, akıllı kent yaklaşımı bağlamında aşağıda yer verildiği gibi açıklanmaktadır.

- Yenilik: YL'lerin varlığı büyük oranda yenilik ihtiyacına dayanmaktadır. YL platformunun kendine ait özgün yapısı üzerinden gerçekleştirilen yeniliklerle kentin yaşam kalitesine katkı sağlamak amaçlanmaktadır (Folstad \& Karahasanovic, 2015: 430; Leminen \& Westerlund, 2015).

- Kullanıcı odaklılık: Burada kast edilen kentte yaşayan vatandaşlardır. Yenilik sürecinde kentte sunulan hizmetlerden yararlanan taraf olarak vatandaşlar, özellikle karşılaşılan sorunların ve ihtiyaçların tespitinde önemli olmaktadır (Evans vd., 2018: 417).

- Gerçek yaşam: Kullanıcı katılımıyla birlikte önemli olan bir başka husus, gerek ürün veya hizmetlerin tasarlanmasında, gerekse de tasarlanan ürün veya hizmetlerin ön izlemesinde gerçek uygulama ortamlarından yararlanılmasıdır. 
- Paydaşlar: Kent sorunlarının karmaşık yapısı, kullanıcının dışında farklı tarafları gündeme getirmektedir. Gerek labların oluşum aşamasında gerekse de yeniliklerin geliştirilmesi ve hayata geçirilmesi sürecinden kamu, özel ve sivil toplumdan, farklı türlerde örgütlü tarafların varlığı önemli olmaktadır (Stahlbröst vd., 2015: 7-9).

- Birlikte/ortak üretim: Paydaşlarla ve kullanıcılarla ilintili bir diğer husus, lablarda yer alan tarafların birlikte çalışabilirliğidir. Bu haliyle lablar, bir yönetişim yapısını yansitmaktadır (Bulkeley vd., 2016: 14).

$\mathrm{Bu}$ adı geçen unsurlar önemle dikkate alınıp hayata geçirildiğinde, vatandaşların ve diğer tarafların katılımıyla beklentilere cevap verecek yeni çözümler hayata geçebilecektir.

\section{Araştırmanın Amacı, Önemi, Kapsamı ve Sınırıııkları}

Araştırmada YL'ler, akıllı kentlerin yenilik üretme aracı olarak konumlandırılmakta ve bu bağlamda inceleme konusu yapılmaktadır. Temelde "kentin sorunlart ve ihtiyaçlarına teknoloji odaklı çözüm üretme sürecinde yaşam laboratuvarları nasıl bir role sahiptir? ”sorusunun cevabi aranmaktadir.

Yeni teknolojilerin kentsel alana yansımasıyla ortaya çıkan teknoloji tabanlı kentsel olgu "akıllı kent" kavramı ile daha çok ifade edilmeye başlanmış ve uluslararası düzeyde önemli bir literatür ortaya çıkmıştır/çıkmaktadır (Sadioğlu \& Erdinçler, 2019). Akıllı kentlerle de ilişkili olarak gündeme gelen bir diğer kavram da YL'lerdir. Bu konuda da uluslararası düzeyde önemli bir literatürün ortaya çıktığg görülmektedir. Diğer taraftan ulusal literatürde "akıllı kent" kavramı akademik düzeyde yeni yeni ortaya çıkarken, YL kavramını gündeme alan bir çalışma tespit edilememiştir. Bu bağlamda araştırmada, ortaya çıkan kentsel sorunlara teknoloji odaklı çözüm üretme sürecinde önemli bir rol yüklenen YL'lerin konu alınması, araştırmanın önemini ortaya çıkarmaktadır.

Türkiye' de YL sertifikasını alan dört belediyenin olduğu bilinmektedir. Bunlar; İstanbul Büyükşehir Belediyesi ${ }^{1}$, Eskişehir Büyükşehir Belediyesi, Tepebaşı Belediyesi (Eskişehir) ve Başakşehir Belediyesi (İstanbul). Fakat adı geçen belediyeler arasında, YL konseptini aktif biçimde Başakşehir Belediyesi'nin yürüttüğü anlaşılmaktadır. Bu bağlamda araştırmanın kapsamını BYL, diğer adıyla "Başakşehir İnovasyon ve Teknoloji Merkezi” oluşturmaktadır. Başakşehir, 2008 yılında ilçe statüsünü elde etmiş, on mahalleden oluşan bir kentsel alana karşılık gelmektedir. 2018 yılı verilerine göre Başakşehir'in nüfusu 396.729'dur. BYL'nin kurulumu Başakşehir Belediyesi'nin girişimiyle 2012 yılında gerçekleşmiş, 2014 yılında halka ve girişimcilere kapılarını açmıştır. BYL'nin temel amacı, "bilişim teknolojileri ve tasarım tabanlı inovasyon ve girişimciliği yaymak ve yeni iş oluşumlarına ortam sağlamak”şeklinde belirtilmektedir (Başakşehir Living Lab, 2019a), 29. leyiş açısından BYL değerlendirme konusu yapılmaktadır. Yani bir YL kapsamında gerçekleşen yenilik sürecinin (bkz. Coenen vd., 2014) veya etkilerini ölçmeye yönelik bir çalışma yapılmamaktadır (Ballon vd., 2018). Ayrıca yöntem kısmında da yer verildiği üzere, mülakatlar, YL yöneticisi ve belediye yetkilisiyle gerçekleştirilmiştir. YL ile ilişkili olan diğer taraflarla (yararlananlar, firma temsilcileri, kullanıcılar gibi) mülakat gerçekleştirilmemiştir. Bu taraflarında; odak grup görüşmesi, katılımcı gözlem gibi yöntemlerle dahil edildiği araştırmalar, YL'lerin sorun alanlarının tespit

1 İBB, “İstanbul City Lab Deneyim Merkezi-Zemin İstanbul” oluşumu kapsamında girişimcilik ağırlıklı çalışmalarını sürdürdüğü anlaşılmaktadır (https://zeministanbul.ist/). 
edilmesinde katkı sağlayabilecektir. İfade edilen noktalar araştırmanın temel sınırlılıklarını oluşturmaktadır.

\section{Araştırmanın Yöntemi}

YL'leri gerek teori (Folstad, 2008; Franz, 2015; Schuurman vd., 2016; McLoughlin vd., 2018; Westerlund vd., 2018; Hossain vd., 2019; Habibipour, 2018) üzerinden, gerekse de uygulamalar (bkz. Schuurman, 2015; Schuurman vd., 2013; Puerari vd., 2018; Nesti, 2017; Leminen, 2015; Leminen vd.,2016; Kviselius vd., ?; Scholl \& Kemp, 2016; Almirall \& Wareham, 2011; Katzy \& Bücker, 2015; Leminen \& Westerlund, 2015; Mengual vd., 2018; Graczyk, 2015; Brask, 2015; Abeysinghe, 2016; Menny, 2016; Bakker vd., 2017; Menny vd., 2018; Sharp \& Salter, 2017; Juujarvi \& Pesso, 2013; Baccarne vd., 2014b; Bifulco vd., 2017; Canzler vd., 2017; Rodrigues \& Franco, 2018; Gasco, 2017; Mengual vd., 2018) üzerinden inceleyen önemli bir literatürün ortaya çıktığg 1 görülmektedir. Di ̌̆er taraftan YL'lerle ilgili araştırmalarda, ağırlıklı olarak nitel araştırma yöntemlerinin öne çıkmakta olduğu anlaşılmaktadır. Bu yöntem kapsamında farklı veri toplama araçları (gözlem, doküman, mülakat gibi) kullanılmaktadır.

İlgili literatürden yararlanarak, belirlenen ana unsurlar üzerinden şu sorular kapsamında inceleme gerçekleştirilmektedir:

- Ortaya çıkışı, altyapısı ve örgütlenmesi

○ BYL, nasıl ortaya çıkmıştır?

○ BYL, nasıl bir fiziksel altyapıyı barındırmaktadır?

○ BYL, nasıl bir örgütsel yapıya sahiptir?

○ BYL, nasıl bir sosyal altyapıyı (insan kaynağı, gönüllüler, teşvik eden unsurlar gibi) barındırmaktadır?

- Kullanıc1/yararlanıcı katılımı (nasıl yapılıyor?)

○ Kullanıcı deneyiminden nasıl yararlanılmaktadır?

○ Oluşturulan imkânlardan ilgililerin yararlanması nasıl gerçekleşmektedir? Tesadüfi mi, odak grup şeklinde mi?

- Farklı tarafların varlığg ve birlikteliği

- BYL'de hangi taraflar yer almakta, hangi rolleri yerine getirmekte ve bu taraflar arasında nasıl bir işbirliği yapısı bulunmaktadır? (yararlanıcılar, imkân sağlayanlar, destekçiler, kullanıcılar ve araştırmacılar kimler?)

- Birlikte üretim

- Taraflar arasında birlikte üretim nasıl gerçekleşmekte ve hangi yöntemler kullanılmaktadır? (Formal fiziksel bir mekanda çalışma mı?,İnformal mekanlarda çalışma mı?).

- Gerçek yaşam ortamı

○ Tasarım ve uygulama aşamalarında gerçek yaşam ortamlarından nasıl 
yararlanılmaktadır?

- Yenilik üretme ve uygulamaya aktarılması

○ Gerçekleştirilen faaliyetlerle elde edilen çıktılar nelerdir?

İfade edilen sorular bağlamında, araştırmada verilerin elde edilmesinde iki niteliksel yöntemden yararlanılmıştır. Birincisi, yarı yapılandırılmış mülakat gerçekleştirilmiştir. İkincisi ise, ilgili dokümanlardan (aylık yayınlanan e-bülten, faaliyet raporu, BYL web sayfası vb.) yararlanılmıştır. Mülakatlar, YL'nin yönetiminden sorumlu olan yönetici (2012 yılından itibaren BYL yönetiminde yer alan koordinatör yardımcısı, BYL KY) ve belediye yetkilisi (BY) (Başakşehir Belediyesi Bilgi İşlem Müdürlüğünde çalışan, BYL'nin çalışmalarında kuruluş aşamasından itibaren yer alan bilgisayar mühendisi) ile 1 Eylül 2018 tarihinde gerçekleştirilmiştir. Mülakat ses kaydı alınarak ortalama 2 saatte gerçekleşmiş olup, ayrıca görevlilerin refakatinde BYL'de teknik olarak inceleme yapılmıştır.

\section{Bulgular}

\subsection{BYL'nin Ortaya Çıkışı}

Başakşehir ilçesi, 2008 yılında kurulumu gerçekleştirilmiş bir idari birimdir. Bu anlamda yeni şekillenen ve genişleyen bir yerleşim alanı olması, akıllı kent uygulamaları açısından bazı avantajları barındırmaktadır. Hatta inşaat ruhsatının alınması için bir dönem fiber obtik altyapı zorunluluğu getirilmiştir. Tamda bu noktada BYL'nin ortaya çıkışında temel etken olarak, yeni kentsel alanı "teknoloji odaklı" geliştirme ve kalkındırma çabası yer almaktadır (BY, 01 . 08. 2018). Ífade edilen çaba kapsamında gerçekleştirilen teknik incelemeler (Sophia-Antipolis/ Fransa) ve getirilen önerilerle YL yaklaşımı benimsenmiş ve ilk adımları 2011 yılında atılmıştır. Öneriler arasında farklı modeller gündeme getirilmiş olsa da, özellikle vatandaşa dokunan ve hizmetleri kapsayan bir yapının olmasına özen gösterildiği vurgulanmaktadır (BY, 01. 09. 2018).BYL, bütün paydaşların bir araya geldiği akıllı şehirciliğin en önemli kilometre taşı, bilişim teknolojileri ve tasarım konulu ürün ve hizmetlerin, gerçek yaşam ortamında, gerçek kullanıcılarla test edilip gerçekleştirildiği bir ortam olarak konumlandırılmaktadır (BY, 01 . 09. 2018). Diğer bir ifadeyle BYL'nin varlığı; bilişim teknolojileri odaklı ürün ve hizmetlerin geliştirilmesi ve gerçek yaşam ortamında test edilmesine dayandırılmaktadır.

BYL, 1 GB hız kapasiteli fiber optik internet altyapısı, örnek uygulamaların gösterimi, dizayn edilen çalışma ortamları, sosyal alanlarıyla yapımı gerçekleşen, Gold seviyede LEED yeşil sertifikaya sahip binasıyla 2014 yılında kapılarını açmıştır (http://basaksehir-livinglab. com/BLL/hakkimizda/, 20. 04. 2019). İstenen YL kriterlerinde fiziksel imkân zorunluluğunun bulunmadığ işlerlik kazanmasına katkı sunulmaya çalışıldığı anlaşılmaktadır (BY, 01. 09. 2018). Ayrıca iç tasarım yapısıyla (bkz. Foto 1), bugünkü beklentilere daha fazla karşılık verilmesine de çaba sarf edildiği vurgulanmaktadır (BYL KY, 01. 09. 2018). 


\section{Foto 1: BYL Ortamı}

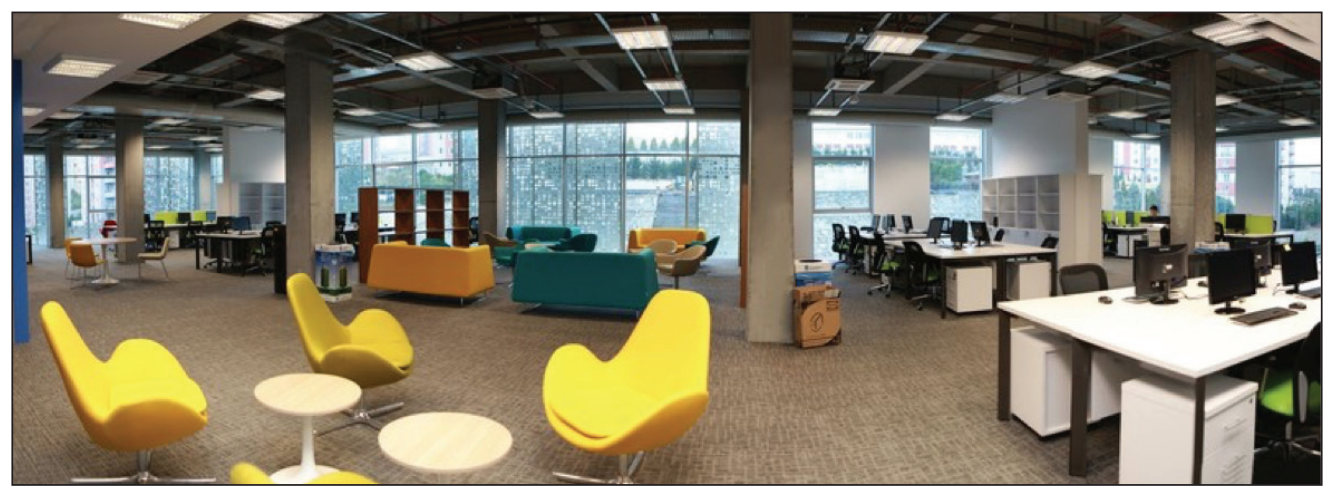

Kaynak:https://www.thinkwithturkiye.com/basaksehir-living-lab-teknoloji-inovasyon-merkezi/ (21. 04. 2019).

Diğer taraftan BYL, belirlenen üyelik kriterlerini sağlayarak 2012 yılında ENOLL'a "effective members" statüsünde (yönetim kurulunda yer alma imkânı vermekte) üyeliğe kabul edilmiştir (yıllık üyelik bedeli $5.000 \mathrm{EU})^{2}$.

\subsection{BYL'nin Kurumsal Yapısı, Paydaşları ve İşleyişi}

BYL, BB Bilgi İşlem Müdürlüğüne bağlı bir birim olarak faaliyetlerini yürütmektedir. Bütçesi (yıllık ayrılan ortalama bütçe 2,5-3 milyon TL) de büyük oranda BB tarafından karşılanan BYL'nin yönetimi, belirlenen şartname kapsamında özel sektöre yıllık olarak ihale edilmektedir. İnsan kaynağı yapısının ise, yönetimi üstlenen firma çalışanları, belediye personeli ve gönüllülerden oluştuğu ifade edilmektedir (BY, 01. 08. 2018).

BYL'nin paydaş yapısı incelendiğinde, farklı konu ve alanlarda tarafların yer aldığı ve işbirliği içinde olunduğu, bu anlamda değişkenlik gösterdiği anlaşılmaktadır (Başakşehir Living Lab, 2019b).

Gerçekleştirilen görüşmede bu paydaşların hepsinin aktif olarak yer almadığı, bazılarının aktif olarak öne çıktığı vurgulanmaktadır. BYL çalışmalarında aktif olarak yer alan paydaşlar; İstanbul Design Factory (BYL içinde ayrı bir çalışma alanı bulunmakta), Borsa İstanbul Başakşehir Mesleki ve Teknik Anadolu Lisesi (robot eğitimleri), Bahçeşehir Fen ve Teknoloji Lisesi (Dron ve robot eğitimleri), Kayaşehir İmam Hatip Lisesi (sanal gerçeklik), Bahçeşehir Koleji şeklinde ifade edilmektedir. Adı geçen çalışmalarda daha çok öğretmenlerin/ öğretim elemanlarının ve öğrencilerin birlikte yer aldığı ve BYL bünyesinde ilgili çalışmaların eğitimlerini yürüttükleri anlaşılmaktadır. BYL'nin kuruluş aşamasında sadece TTNET ile protokole dayalı bir anlaşma yürütüldüğüu, bunun dışında işbirliği süreçlerinin çoğu zaman gönüllük üzerinden gerçekleştiği belirtilmektedir. Ve gönüllülük üzerinden gerçekleştirilen işbirliklerinin daha verimli olduğu ifade edilmektedir. Hatta bir “BYL gönüllülleri” gibi biçimsel yapı oluşturulmak istenmiş, fakat hayata geçirilmemiştir. Ayrıca bu paydaşlar arasındaki

2 Burada belirtmek gerekir ki, BB'nin 2019 yılı bütçesi 540 milyon lira olarak belirlenmiştir (https://basaksehir.bel. tr/haberler/belediye-meclisi-2019-butcesini-onaylandi-3506, 05. 05. 2019) 
işbirliklerinde ilişkilerin önce bireysel düzeyde (belediye personeli üzerinden) başlatıldı̆̆ sonrasında kurumsal seviyeye çıkarıldığının altı çizilmektedir (BY, 01.09. 2018).

Diğer taraftan paydaşlar arası işbirliklerinin geliştirilmesine yönelik de bir çabanın sergilendiği, aylık bültenlerdeki ayrıca yer verilmesinden anlaşılmaktadır (Başakşehir Living Lab, 2019c).

\subsection{BYL'nin Odaklandığı Alanlar}

İlgili literatür incelemesinde görüldüğü gibi YL'ler, farklı konu ve alanlarda çalışmalarını yürütmektedir. Gerçekleştirilen görüşmede (BY, 01. 08. 2018), BYL yönetiminin özel sektöre devir sürecinde hazırlanan şartnamede üç hususa vurgu yapıldığı ifade edilmektedir. $\mathrm{Bu}$ hususların birincisi, girişimcilik düzeyinin artırılması ve kuluçka hizmetlerinin verilmesi; ikincisi, vatandaşın; teknoloji, tasarım ve girişimcilik konusunda bilgisinin artırılması ve üçüncüsü ise, yeni teknolojik ürünlerin vatandaşa tanıtılmasıdır. Yani BYL çalışmaları dar anlamda sadece belediye hizmetlerine indirgenmiş durumunun bulunmadığı, genel çerçevede kentte çeşitli açılardan katkı sağlamayı amaç edindiği anlaşılmaktadır.

Vatandaşın yaşamını kolaylaştırma amacı kapsamında BYL’nin odak alanları Tablo 1 'deki başlıklar altında toplanmaktadır.

\section{Tablo 1: BYL'nin Odak Alanları}

\begin{tabular}{ll}
\hline Akıllı Yaşam & Tasarım \\
\hline Akıllı Şehircilik & Mobil Sağlık \\
\hline Mobil Uygulamalar & Bilgi Teknolojileri Eğitimleri \\
\hline Robotik & Yenilenebilir ve Akıllı Enerji Sistemleri \\
\hline Kablosuz İletişim & Bilgi Teknolojileri ve Yazılım \\
\hline Giyilebilir Teknolojiler & Sensör Teknolojileri \\
\hline
\end{tabular}

Kaynak: http://basaksehir-livinglab.com/BLL/hakkimizda/living-lab-nedir/, 25. 04. 2019)

Belirtilen odak alanları kapsamında "kullanıcı odaklılık" ve "birlikte üretim" ilkelerini merkeze yerleştirerek, BYL faaliyetlerinin sürdürüldüğü anlaşılmaktadır (BY, 01. 09. 2018).

\subsection{BYL'nin Sunduğu İmkânlar ve İşlevleri}

BYL'de, profesyonellerden ziyade daha çok girişimci adaylarına ve belediye hizmetlerinin geliştirilmesine yönelik imkânlar sunulmaktadır. BYL ortam olarak temelde; kullanıcı deneyim merkezi, kuluçka merkezi ve sosyal alanlardan oluşmaktadır. Bu alanlarda; elektrolab, toplantı ve seminer salonları, görüntülü görüşme kabinleri, arduino eğitimlerinin verildiği elektronik laboratuvar, 3D printerlerin yer aldığı endüstriyel tasarım atölyesi, akıllı tahta, dijital oyun alanı gibi bölümler yer almaktadır. Gerçekleştirilen bu faaliyetlerle BYL, "araştırma, test etme ve yenilik" ortamı sunmaktadır. 


\section{Şekil 2: BYL'nin Temel İşlevleri}

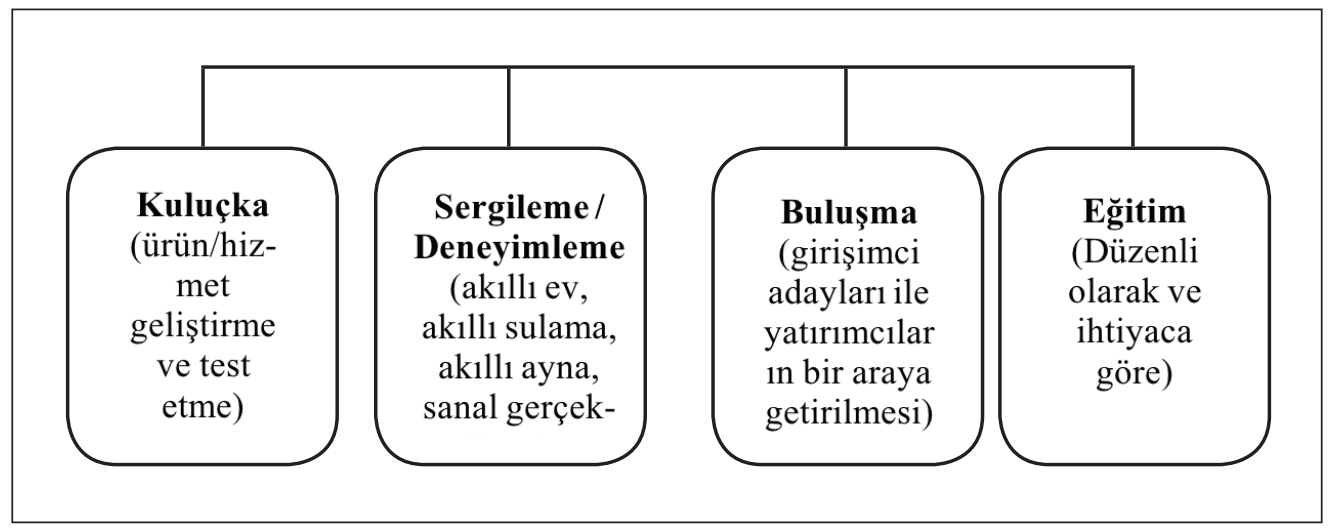

Sahip olduğu imkânlarla BYL'nin işlevine katkı sağlayan dört önemli bölümünün olduğu anlaşılmaktadır (bkz. Şekil 2). Birincisi, kuluçka (incubator) merkezidir. Bu merkezde, fikirlerin ürüne veya hizmete dönüşmesine yönelik imkânlar sunulmaktadır. İkincisi, kullanıcı deneyim merkezidir. Bu merkezde geliştirilen ürün ve hizmetler, kullanıcısıyla veya iş ortaklarıyla buluşturulmakta ve test edilmektedir. Üçüncüsü, sosyal alandır. Bu alan BYL'ye dahil olan kişilerin (girişimciler, girişimci adayları ve yatırımcılar), çeşitli yöntemlerle iş ve sosyal ilişkilerin geliştirildiği bir alandır. Dördüncüsü, düzenli olarak ve ihtiyaca göre, çeşitli yöntemlerle gerçekleştirilen eğitimlerdir.

İş fikirlerinin olgunlaştığ 1 bir fiziksel ortamı yansıtan kuluçka merkezleri, girişimci adaylarının önemli başvuru noktalarından biri haline gelmiş durumdadır. BYL bünyesinde bulunan bu merkezde, işlerin fikirden ürüne veya hizmete dönüştürülmesi ve test edilmesi için gerekli imkânların sağlanmaya çalışıldığı anlaşılmaktadır. Uygulamalara katılım gösterenlerin, geliştirilen ürüne/hizmete göre değişkenlik gösterdiğ ${ }^{3}$ ve teşvik etmek için de küçük hediyelerin verildiği bildirilmektedir. Gerçekleştirilen çalışmalara katılımın sağlanması noktasında ilk dönemlerde zorluk yaşandığı, sonraki dönemlerde belirli bir rutin oluştuğu, web üzerinden gerekli bilgilendirme yapıldığında katılımın sağlandığı belirtilmektedir (BY, 01. 09. 2018).

Geliştirilen ürünlerin sunulması, gelişen teknolojilerin gerçek yaşamla bağlantı kurması açısından önemli olmaktadır. Yani vatandaş, gelişen teknolojinin günlük yaşam pratiğine yansımalarını, geliştirilen ürünleri inceleyerek-deneyerek görebilme imkânına sahip

3 Örneğin geliştirilen mobil kelime oyunun testi için çağrıya çıkılmış (SMS, e-mail vb. araçlarla) ve BYL'ye gelen genç kullanıcılar üzerinden test işlemi gerçekleştirilmiştir. Yine BYL'nin katkısıyla geliştirilen Mobil Sağlık İstasyonu ürününün testi Belediye ve BYL binası içinde yaşlılar tarafından gerçekleştirilmiştir. Hatta belediye tarafından gezici hale getirilerek vatandaşın bulunduğu noktalarda yaygınlaştırılması sağlanmıştır. Diğer taraftan test işlemlerinin de kimi zaman yerinde yapıldığı görülmektedir. Örneğin sanal gerçeklik gibi bir teknoloji tanıtılmak istendiğinde bir site yönetimiyle iş birliğine gidildiği, belirlenen gün ve saatin site yönetimi üzerinden site sakinlerine duyularak gerçekleştiği ifade edilmektedir. Yine akıllı park sitemi uygulaması BYL binasının ön kısmına kurularak test edilmeye çalışıldığı ve buradan elde edilen sonuçlarla yaygınlaştırılmaya çalışılacağ 1 belirtilmektedir. Benzer şekilde dijital tabela ürünün belediye ortamında test edilmesi sağlanmış, elde edilen olumlu sonuçlarla uygulama belediye içinde yaygınlaştırılmıştır. Kimi zamanda test işleminin profesyonel gruplar (bilgi evleri öğretmenleri) üzerinden gerçekleştirildiği ifade edilmektedir (BY, 01. 09. 2018). 
olmaktadır. Sergileme işleminin, kimi zaman BYL mekanının dışında (sitelerde, sokakta, fuar alanlarında) da gerçekleştirildiği ifade edilmektedir (BY, 01.09. 2018).

BYL'nin bir diğer işlevi farklı tarafları buluşturmasıdır. Yapılan çeşitli etkinlikler ile girişimci adayları ile yatırımcılar buluşturulmaya, bunun üzerinden ürünlerin veya hizmetlerin piyasada yaygınlık kazanmasına çaba sarf edilmektedir. Ayrıca sunulan sosyal alanlarla farklı tarafların buluşmasına katkı sağlanmaya çalışıldığı belirtilmektedir (BY, 01. 09. 2018).

BYL, fiziksel imkânları kadar, gerçekleştirdiği eğitim, atölye, çalıştay, hackathon ${ }^{4}$, yarışma ve özel gün etkinlikleriyle de öne çıkmaktadır. Bu bağlamda daha çok teknoloji ve girişim odaklı, yaratıcılığı ve kişisel yetenekleri ön plana çıkartan eğitimler ${ }^{5}$ gerçekleştirilmektedir. Hangi eğitimlerin gerçekleşeceği, elde edilen tecrübelere ve ihtiyaca göre belediye tarafından şartnamede yer verildiği ifade edilmektedir (BY, 01. 08. 2018). Bu eğitimlerin bir kısmının düzenli olarak belli aralıklarla gerçekleştiği (ayda iki kez gerçekleşen girişimcilik eğitimi, programlama eğitimleri gibi) bir kısmının ise ihtiyaca göre gerçekleştiği anlaşılmaktadır. Bu çalışmalar; güncel bilişim teknolojileri eğitimi, tasarım eğitimi, girişimci eğitimleri, mekatronik $^{6}$ ve robot eğitimleri başlıkları altında toplanabilir. Kimi zaman belediye personellerine yönelik de eğitimlerin gerçekleştiği belirtilmektedir. Bu eğitimlerle gelişen teknolojilerin belediye hizmetlerine yansıtılmaya çalışıldığı ve yeni teknoloji içerikli belediye uygulamalarının öğretilmeye çalışıldığ dijital saat, SketchUp ${ }^{7}$ ve kâğıt işleri gibi) çalıştayların da yürütüldüğü görülmektedir.

Diğer taraftan faklı hedef kitleler dikkate alınarak çeşitli atölye çalışmalarının yürütüldüğü tespit edilmektedir ${ }^{8}$. Yine girişimciliği ve yeniliği teşvik etmek amacıyla belli aralıklarla girişimci adayları ile yatırımcıların bir araya getirildiği girişimci günü ${ }^{9}$ ve yenilik yarışmalarının ${ }^{10}$ düzenlendiği görülmektedir. Bu etkinliklerde, gelen başvurular değerlendirilmekte, dereceye girenlere ödüller verilmektedir. Ayrıca girişimci günü etkinliklerinde jüri (öğretim elemanları, sektör temsilcileri ve belediye personelinden oluşmakta) tarafından değerli bulunan girişimlere, BYL'nin fiziksel imkânları, belirli bir süre sunulmakta olduğu anlaşılmaktadır. Yıllar itibariyle gelen başvuruların niteliğinin artığ 1 , ayrıca belirtilmektedir (BYL KY, 01. 09.

4 Farklı isimlerle de ifade edilen bu etkinlik, yazılım yarışmalarını kapsamaktadır. Bir grup insanın bir araya gelerek, 1-2 gün boyunca ayrılmadan gerçekleştirdikleri yazılım etkinliği olarak açıklanmaktadır. https://toptalent.co/hackathon-nedir\#: :text=Hackathon $\% 20$ genellikle $\% 20 y a z \% C 4 \%$ B $11 \% \mathrm{C} 4 \% \mathrm{~B} 1 \mathrm{~m} \% 20$ geli\%C5\%9Ftiricilerinin $\% 2 \mathrm{C} \% 20$ aray $\% \mathrm{C} 3 \% \mathrm{BCz}, \mathrm{yeni} \% 20$ bir $\% 20$ proje $\% 20$ geli $\%$ C5\%9Ftirdikleri\% 20 yar\%C4\%B1\%C5\%9Fmad\%C4\%B1r, 10.09. 2020.

52018 yılında gerçekleştirilen eğitimlerin bir kısmı şunlardır: 360 derece e-ticaret, minik parmaklar kodlama eğitimi, cloud teknolojileri ve veri yönetimi, kaynaklara erişim eğitimi, web tasarımı eğitimi, mobil oyun programlama, strateji ve iş geliştirme eğitimi, after effect temel eğitimi akıllı şehircilik hackathon'una hazırlık eğitimi vb.

6 Mekanik ve elektroniğin bir araya gelerek yeni bir yapının ortaya çıkarılması mekatronik olarak ifade edilmektedir. https://tr.wikipedia.org/wiki/Mekatronik\#: :text=Mekatronik\%2C\%20mekanik\%20ve\%20elektronik\%20 kelimelerinin,Mekatronik\%20kelimesi\%20ayn\%C4\%B1\%20zamanda\%20Avrupa, 10. 09. 2020.

7 3B modelleme yazılımlarına verilen genel addır. https://tr.wikipedia.org/wiki/SketchUp,10. 09. 2020.

82018 yılında gerçekleştirilen atölye çalışmalarının bir kısmı şunlardır: dijital dizayn atölyesi, karakalem çizim atölyesi, yaratıcı kitaplık tasarım atölyesi, fonksiyonel mobilya tasarım atölyesi, lego ile insansız araçlar atölyesi, düzen kuşağı atölyesi vb.

9 Ortalama olarak yılda iki kez gerçekleştiği anlaşılan bu etkinliğin sekizincisi yürütülmektedir. Burada katılım sağlayan firmalar; belediyenin hizmet süreçlerinde yer alan firmalar,

10 Yılda bir kez gerçekleştirilmekte olup (Aralık ayında), şimdiye kadar beş kez gerçekleştirildiği anlaşılmaktadır. Yarışma; ortaokul, lise, üniversite, öğretmen ve öğretim görevlisi kategorilerinde gerçekleşmektedir. 
2018). Burada vurgulanması gereken başka bir husus da, İstanbul dışından (Niğde, Uşak gibi illerden) başvuruların olmasıdır. Özellikle teknik liselerden öğrenci ve öğretmen kategorisinde başvurular dikkat çekmektedir (BY,01. 09. 2018). Bu etkinlikler, BYL'nin bulunduğu fiziksel alanın dışına çıkarak etkisini artırdığını göstermektedir.

Yeniliğin ortaya çıkması açısından dikkat çeken BYL faaliyetlerinden biri de yazılım maratonları olarak dilimize aktaracağımız "hackathonlardır". Genellikle bir konu üzerinde yoğunlaştırılmış biçimde 24-48 saat sürdürülen çalışmalar olarak ifade edilmektedir. BYL bünyesinde ortalama olarak her yıl iki günü kapsayacak şekilde bir kez düzenlendiğ $i^{11}$ anlaşılmaktadır. Üniversite öğrencilerinin katılımıyla bu etkinliklerin gerçekleştirildiği anlaşılmaktadır.

Bunların dışında fuarlara (yurt içi ve yurt dışı) katılım sağlanarak, girişimci adayları ile yatırımcıların buluşturulması çabasının da gösterildiği; yine öğrencilere, vatandaşlara ve işletmelere yönelik BYL'nin bilinirliğini artırıcı tanıtım çalışmalarının (her ay) yürütüldüŭgü ifade edilmektedir.

\subsection{BYL'nin İşleyişi, Paydaşların Konumu, Gerçekleştirilen Faaliyetler ve Çıktılar}

Girişimci adayları ve ürününü/hizmetini geliştirmek isteyen küçük işletmeler için BYL'nin işleyiş aşamaları aşağıda yer verilmektedir.

- Birinci aşama: Başvuru işlemleri (BYL'nin web sayfası üzerinde yer verilen “fikir potası" ve "girişim başvurusu" bölümlerinden gerçekleşmekte).

- İkinci aşama: Görüşme zamanının belirlenmesi.

- Üçüncü aşama: Görüşmenin gerçekleşmesi (İş planı, ihtiyaçlar, vb. bağlamında projenin sunumunun girişimci adayı tarafından yapılması).

- Dördüncü aşama: Kabul veya red edilmesi.

- Beşinci aşama: Sözleşmenin gerçekleştirilmesi ve imkânların sunulması (sunulan imkânlardan yararlanmayı kapsayan bir yıllık iyi niyet antlaşmasının imzalanması).

Girişimci adayı kabul aldıktan sonra imkânlardan yararlanmasını sağlayan bir kart düzenlendiği ve zaman içinde BYL personeli tarafından girişimcinin çalışmalarının hangi aşamada olduğuna yönelik takipler gerçekleştirildiği ifade edilmektedir (BY, 01. 09. 2019).

BYL'nin imkânları bir fikri olan girişimci adaylarına ve ürününü/hizmetini geliştirmek isteyen küçük işletmelere sunulmaktadır. Bu süreçte gerek ürünün geliştirilmesi aşamasında gerekse de piyasada başarılı olması durumunda, BYL herhangi bir ücret veya pay almadığı vurgulanmaktadır. İfade edilenler çerçevesinde BYL aşağıda yer verilen üç temel açıdan katkı sağladı̆̆

- Sifırdan bir fikrin ürüne dönüşmesine aracı olmak (fikir, ürün, test ve uygulama süreciyle)

- Geliştirilmiş bir ürünün test edilmesine aracı olmak (test ve uygulama süreciyle)

- Geliştirilmiş bir ürünün yaygınlık kazanmasına aracı olmak (sadece uygulamayla)

11 Şu konularda hackathonların düzenlendiği tespit edilmektedir: 2-4 Mayıs 2014, akıllı şehircilik ve belediye uygulamaları; 24-25 Ekim 2015 3D yazıcılar; 28-29 Nisan 2017 Akıllı kent uygulamaları; 07-08 Nisan 2018 Akıllı kent uygulamaları. 
BYL kapsamında gerçekleştirilen faaliyetler ve bu faaliyetler içinde işbirliği yapılan taraflar aşağıda yer verilmektedir.

Tablo 2: Gerçekleştirilen Faaliyetlerde İş Birliği Yapılan Paydaşlar

\begin{tabular}{ll}
\hline \multicolumn{1}{c}{ Faaliyetler } & \multicolumn{1}{c}{ İş birliği yapılan taraflar } \\
\hline İmkanlardan yararlananlar & $*$ Üniversite öğrencileri ve öğretim elemanları, \\
& $*$ Lise öğrencileri ve öğretmenleri, \\
& $*$ Belediye personeli, \\
& $*$ Girişimci adayları, \\
& $*$ Ürününü geliştirmek isteyen işletmeler (girişimin ilk \\
& evrelerinde olan işletmeler), \\
& $*$ Vatandaşlar \\
\hline Eğitim faaliyetlerinde yer & $*$ Çöpüne Sahip Çık Vakfı ve PAGÇEV (Türk Plastik \\
alanlar & Sanayicileri Araştırma Geliştirme ve Eğitim Vakfı) \\
& $*$ Üniversite öğrenci ve akademisyenleri \\
& $*$ Lise öğrencileri ve öğretmenleri, \\
& $*$ Belediye çalışanları, \\
\hline Ürünlerin test edilmesi, günlük & $*$ Siteler, Başakşehir Belediyesi, mahalleler, bilgi evleri (7 \\
yaşamla ilişki kurulmasında & adet), sosyal etkinlik alanları, spor alanları, AVM, vb. \\
yer alanlar & \\
\hline Ürünlerin yaygınlık kazanması & $*$ Yatımcılar (daha çok belediye ile iş yapan firmalar) \\
sürecinde yer alanlar & $*$ Başakşehir Belediyesi \\
\hline
\end{tabular}

Aşağıda yer verilen Tablo 3 ve Tablo 4'de de 2014-2016 yılları arasında gerçekleştirilen faaliyetler yer almaktadır. Tablo 3 incelendiğinde yıllar itibariyle gerek etkinlik sayısında, gerekse de proje, eğitimlere katılım ve ziyaretçilerin sayılarında bir artışın olduğu görülmektedir. Özellikle gerçekleştirilen eğitimlere ve çalıştaylara katılımın önemli düzeyde artış göstermesi dikkat çekmektedir.

Tablo 4 de ise 2017 yılı baz alınarak, yapılan çalışmaların saat türünden verileri yer almaktadır.

\section{Tablo 3: BYL Faaliyetleri (2014-2016)}

\begin{tabular}{lccc}
\hline BYL'nin Faaliyetleri & $\mathbf{2 0 1 4}$ & $\mathbf{2 0 1 5}$ & $\mathbf{2 0 1 6}$ \\
\hline Gerçekleştirilen eğitim ve çalıştay sayısı & 19 & 83 & 84 \\
\hline Eğitim ve çalıştaylara katılım sayısı & 625 & 1600 & 2935 \\
\hline Girişimci ve proje sayısı & $12(25$ kişi $)$ & $16(30$ kişi $)$ & 15 (38 kişi) \\
\hline Ziyaretçi sayısı & 78 & 131 & 158 \\
\hline
\end{tabular}


Tablo 4: BYL 2017 Yılı Faaliyetleri (Saat Türünden)

\begin{tabular}{lc}
\hline BYL'de Gerçekleştirilen 2017 Yılı Faaliyetleri & Saati \\
\hline Bilişim ve teknoloji etkinlikleri & 370 \\
\hline Girişimci tasarım, iş geliştirme, satış ve pazarlama destekleri & 210 \\
\hline Girişimciliği destekleyici etkinlikler & 132 \\
\hline Tasarım etkinlikleri & 120 \\
\hline Mekatronik Teknolojileri Etkinlikleri & 400 \\
\hline Akıllı şehircilik etkinlikleri & 32 \\
\hline Toplam & $\mathbf{1 2 6 4}$ \\
\hline
\end{tabular}

Gerçekleştirilen çıktıların detayları incelendiğinde, BB ve bir şirketin öncülüğünde başlatılan girişimlerin, BYL'nin de katkısıyla hayata geçtiği ve ilçe düzeyinde uygulamaya aktarıldığı görülmektedir (Mobil Sağlık İstasyonu uygulaması). Diğer çıktıların ise, henüz ekonomik anlamda katkı sağlayan, piyasada tüketilen bir ürüne veya hizmete dönüşerek yaygınlık kazanacak bir başarı göstermediği anlaşılmaktadır. Öne çıkan projeler kapsamında BYL'nin kuluçka merkezi ve sergileme imkânlarından yararlandığı tespit edilmektedir. Bir diğer dikkat çeken husus ise, öne çıkan projelerin girişimcisi dışında bir paydaşının olmamasıdır.

\subsection{BYL Bağlamında Karşılaşılan Zorluklar ve Sorun Alanları}

BYL çalışmaları kapsamında karşılaşılan zorluklar ve sorun alanları, görüşmelerden (BP ve BYL KY, 01. 09. 2018) elde edilen bilgiler çerçevesinde aşağıdaki şekilde siralanabilmektedir:

- Girişimcilik sürecinin tam manasıyla anlaşılamaması (başvurusu yapılan projeler ve aday motivasyonuna dayanarak),

- BYL'nin işleyişinde belediye başkanının yaklaşımının belirleyici olması (“Belediye Başkanı'na bir proje sunulduğunda gidin LivingLab'da tartışın diyordu")

- Gerçekleştirilen faaliyetlerin performans ölçümlerinin tam anlamıyla yapılamaması, kriterlerin oluşmaması,

- Yeni bir yaklaşım olarak sosyal alanda 'Laboratuvar' mantığının anlaşılmaması,

- Başakşehir'in bulunduğu konumun potansiyel girişimci adaylarına ve küçük işletmelere uzaklığ

- Potansiyel paydaşların olumsuz tutumu veya geleneksel yapının dışına çıkmama isteğ ${ }^{12}$,

- Girişimci adaylarına verilen destek sonrası takibin olmaması,

- Girişimlerin ekonomik kazanıma dönüşememesi, yatırımcı ve girişimci buluşmalarının tam anlamıyla gerçekleştirilememesi.

12 Bu noktada özellikle ilçe sınırları kapsamında yer alan, 37 sanayi kooperatifi ve toplamda 27.301 işyeri biriminden oluşan (Öztürk, 2019: 190) İkitelli Organize Sanayi Bölgesi’ne dikkat çekilmektedir. 
- Mevcut personel yönetimi yaklaşımından kaynaklanan sinırlılıkların bulunması (ödüllendirmeyi sağlayan bir uygulamanın olmaması)

- Kurumsal düzeye çıkarılmakla birlikte daha çok kişisel ilişkiler üzerinden paydaşlarla iş birliği çalışmalarının yürütülüyor olmasıdır.

\section{Tartışma}

BYL'nin kurulumu 2008 yılında gerçekleşmiş ve 2014 yılında aktif olarak faaliyete başlamıştır. Bu süreçte istenen kriterleri sağlayarak 2012 yılında ENOLL'a "efective members" statüsünde üye olunmuştur. BYL, BB'nin girişimiyle, herhangi bir zaman dilimiyle sınırlandırılmadan ortaya çıkmıştır. Çünkü proje bazlı yapılan çalışmalarda belirlenmiş bir sürenin olması, farklı tarafların dahil edilmesi açısından sınırlılıkları barındırdığının altı çizilmektedir (Nesti, 2017: 7). Oluşum sürecinde Belediye tarafından duyulan ihtiyaç ve gerçekleştirilen teknik gezilerin etkili olduğu anlaşılmaktadır. Ayrıca Başakşehir'in ayrı bir yönetsel ve kentsel alan olarak düzenlenmesi, BYL oluşumunun arkasında başka bir motivasyon kaynağıdır. Diğer YL uygulamaları dikkate alındığında da, belediyelerin ve üniversitelerin öne çıktığı bilinmektedir. Diğer taraftan BYL'nin ortaya çıkmasında ve devamlılı̆̆ının sağlanmasında temel belirleyici etmenin BB Başkanı'nın şahsında toplandığı anlaşılmaktadır. Yerelde güçlü başkan modelinin öne çıkmasıyla bağlantılı olarak, YL gibi oluşumlar, belediye yönetiminin bakış açısına göre şekillenmektedir. Yapılan görüşmede BYL'nin devamlığı konusunda "başkanın sahiplenmesi" durumuna dikkat çekilmekte, yapılan harcamalara karşı belediye tarafına olan katkının ispat edilmesi halinde belediye yönetimin tutumunun olumlu olduğu belirtilmektedir. Bu gibi durumlar YL oluşumunun devamlılığı açısından sorun oluşturabilmektedir.

BYL, akıllı kentte giden süreçte bilişim teknolojileri ve tasarım konulu ürün ve hizmetlerin, gerçek yaşam şartlarında geliştirildiği ve test edildiği bir ortam (çevre) olarak konumlandırılmaktadır. Bu kapsamda belirlenen amacın gerçekleşmesi için ilgili tarafların kullanımına sunulan fiziksel imkânlar (elektronik lab, tasarım atolyesi, dijital oyun alanı, akıllı tahta vb.) bulunmaktadır. Farklı uygulamalarda YL'lerin odak konusuna göre altyapının değişkenlik gösterdiği anlaşılmaktadır (Schuurman, 2015: 254; Gasco, 2017: 92).

BYL, BB Bilgi İşlem Müdürlüğüne bağlı bir birim olmakla birlikte, belirlenen şartname çerçevesinde yönetimi yıllık olarak özel sektöre devir edilmektedir. Bu yöntemle, klasik örgütsel yapının dışında etkinliği artırma çabasının olduğu anlaşılmaktadır.

BYL'nin yapı ve işleyişinde farklı aktörler gösterilmekle birlikte aktif olarak sınırlı düzeyde aktörlerin varlığının olduğu anlaşılmaktadır. Bu aktörler arasında da eğitim kurumlarının öğrenci ve öğretmenleri/öğretim elemanlarıyla öne çıktı̆̆ı görülmektedir. Benzer oluşumlarda öğrencilerin katılımının önemli olduğu tespit edilmektedir (Bakker vd., 2017: 25-26). Fakat farklı taraflarla işbirliklerin geliştirilmesine yönelik ayrıca bir çabanın gösterildiği anlaşılmaktadır. Diğer taraftan ürünlerin/hizmetlerin gerek YL ortamında gerekse de yaşam alanında test edilmesinde vatandaşların katılımının gerçekleştiği belirtilmektedir. YL süreçlerine vatandaşların katılımı önemle vurgulanmaktadır (Nesti, 2017: 4). İspanya' daki bir YL uygulamasında, bir YL'nin 7000 kişiden oluşan aktif üyesinin bulunduğu ve yıllık 25.000 kişiden oluşan ziyaretçilerin olduğu ifade edilmektedir (Gasco, 2017: 93). 
YL'ler farklı konulara odaklanarak faaliyetlerini yürütebilmektedir. Bu odak alanları arasında YL'lerin üzerinde durduğu konulardan biri de akıllı kentlerdir. BYL, teknolojiyi odağına alarak; akıllı yaşam, akıllı şehircilik, mobil uygulamalar, robotik, mobil sağlık, tasarım gibi farklı konu alanlarına ağırlık vermektedir.

YL'ler farklı işlevler üzerine yoğunlaşabilmektedir. İfade edilen yapısıyla BYL dört temel işlevi yerine getirdiği anlaşılmaktadır. Bunlar: kuluçka, sergileme/deneyimleme, buluşma ve eğitimdir. Kuluçka ve sergileme/deneyimleme imkânları, belirli kriterleri sağlayan girişimci adaylarına ve işlerini geliştirmek isteyen küçük işletmelere sunulmaktadır. Kullanıcının test etme işlemi ürüne göre değişkenlik göstermekte ve çeşitli yöntemler kullanılmaktadır. Mahalle düzeyinde ve belediye binası içinde (Nesti, 2017: 9) test işlemi gerçekleşebileceği gibi, bir tablet üzerinden (e-sağlık uygulaması, Schuurman, 2015: 224) de gerçekleşebilmektedir. Girişimcilere yönelik gerçekleştirilen özel gün etkinlikleri ve yarışmalarla, sermaye sahipleri ile girişimci adayları buluşturulmaya çalışılmaktadır. Diğer taraftan YL ortamının sunduğu sosyal alanlarla da farklı tarafların buluşmasına katkı sağladığı belirtilmektedir. BYL'de gerçekleştirilen çeşitli eğitim çalışmaları öne çıkmaktadır. Gerçekleştirilen eğitimlerde, teknoloji ve girişim odaklı yaratıcılığı ve kişisel yetenekleri ön plana çıkarma amacı güdülmektedir. Eğitim çalışmalarına katkı sağlayan, atölye, çalıştay, hackathon gibi etkinliklere de yer verilmektedir.

BYL'nin faaliyette bulunduğu beş yıllık süre dikkate alındığında somut düzeyde çeşitli yeniliklerin ortaya çıtı̆̆ı görülmektedir. Fakat geliştirilen yeniliklerden piyasada başarı gösteren sınırlı sayıda ürünün/hizmetin olduğu anlaşılmaktadır. Bu durumun ortaya çıkmasında çeşitli faktörler etkili olmakla birlikte adayların, girişimci donanımlarının yetersizliğinin (tek seferde başarma isteği, her şeyin karşılanması gibi BYL'den beklentilerin yüksek olması gibi) etkili olduğunun altı çizilmektedir.Diğer taraftan geliştirilen ürünlerin/hizmetlerin bir kısmının üzerinde çalışmaların devam ettiği anlaşılmaktadır. Bu noktada bazı YL'lerin, önemli ekonomik kazanımları ortaya çıkardığı bilinmektedir (bkz. Rodrigues \& Franco, 2018: 785).

Kamusal fayda açısından BYL'nin iki çıktısı öne çıkmaktadır. Birincisi akıllı atık yönetimi, ikincisi ise mobil sağlık istasyonudur. Bu iki ürünün öncesi bulunmakla birlikte, BYL bünyesinde gelişimi ve yaygınlaştırılması sağlanmıştır. Farklı fonksiyonları olmakla birlikte BYL'nin belediye açısından en önemli kazanımının, kentte yönelik teknolojik çözümlerin gerçekleştirilmesi ve belediye ile olan iş ilişkilerinde firmaların tekelci konumunun zayıflaması ifade edilmektedir. Diğer taraftan aynı veya benzer uygulamaları (23 büyükşehir belediye başkanının teknik açıdan ziyarette bulunması) teşvik etmesi dikkat çekmektedir.

Gerçekleşen çıktılar genel olarak incelendiğinde BYL bulguları, daha çok ekonomi ağırlıklı çalışmaların yürütüldüğünü göstermektedir. Farklı YL uygulamalarında ağırlığın değişkenlik gösterdiği bilinmektedir. Örneğin İsveç'de bulunan YL'ler üzerine yapılan çalışmada sosyal ve çevre üzerine bir yoğunlaşmanın olduğu anlaşılmaktadır (Brask, 2015: 30-31).

BYL çalışmaları kapsamında çeşitli zorlukların ve sorun alanlarının varlığına dikkat çekilmektedir. Bu hususlar şunlardır: girişimcilik sürecinin anlaşılmaması, belediye başkanının yaklaşımının belirleyici olması, performans ölçümlerinin tam anlamıyla yapılmaması, YL mantığının sosyal alanda anlaşılmaması, potansiyel paydaşların olumsuz tutumu, yatırımcı ve girişimci buluşmalarının tam anlamıyla gerçekleşmemesi gibi. Burada tespit edildiği gibi 
diğer lab uygulamalarında da benzer hususların altı çizilmektedir. Turin, Amstredam ve Boston kentlerinde bulunan YL'ler üzerine yapılan araştırmada şu sınırlılıkları tespit etmektedir (Nesti, 2017: 12-13): fiziksel yetersizlik gibi nedenlerle iş birliği motivasyonunu sürdürmek, klasik yönetim anlayışından kaynaklanan sınırlılıklar (esneklik gösterilmemesi, kamu kurumlarının paylaşımda bulunmaması gibi) ve sürdürülebilirlik (proje bazlı çabaların dışında rutin politika belirleme süreçlerine YL'lerin nasıl entegre edileceği, finansal kaynakların nasıl sürdürüleceği gibi konular). Gasco (2017: 93-95) tarafından gerçekleştirilen YL incelemesinde de; YL'nin sürdürülebilirliği (ekonomik gerekçelerle sekteye uğrayabilmekte), yapılan yatırımların/ harcamaların geri dönüşümlerinin net olarak bilinmemesi ve politik olarak farklı şekillerde algılanması (sosyalist bir proje olarak görülmesi gibi), insan kaynağı, bilinirlik eksikliği, YL örgütlenmesi üzerinde klasik yönetsel anlayışın etkisini sürdürmesi noktalarında sorun alanları tespit edilmektedir. Ífade edilen sınırlılıklar ve sorun alanlarının bulunmasıyla birlikte YL'lerin işleyişinin devamlılığında üç temel unsurun etkili olduğu tespit edilmektedir: vatandaşların katılım motivasyonları, kent yönetiminin desteği ve altyapısıdır (Gasco, 2017: 93).

\section{Sonuç ve Öneriler}

$\mathrm{Bu}$ araştırmada yaklaşık 5 yıldır aktif faaliyetlerini yürüten BYL inceleme konusu yapılmaktadır. YL'ler, akıllı kent yaklaşımının önemli bir parçası olarak konumlanmaktadır. Burada amaç, karşılaşılan sorunlara teknoloji odaklı çözümler üretme sürecinde, sorunun gerçek yaşam şartlarına dayalı olarak tespit edilmesi ve yine gerçek yaşamda karşılığını bulacak çözümlerin geliştirilerek uygulamaya aktarılmasıdır. Bu süreçte kenti bizzat yaşayan vatandaşlar önemli bir tarafı temsil etmekte ve bunun yanında farklı taraflar önemli rolleri yerine getirmektedir. Bu sayede yeniliklerin ortaya çıkmasına katkı sağlanmaya çalışılmaktadır.

İstanbul'un diğer ilçelerine göre yeni bir yerleşim alanı olan Başakşehir, yönetsel açıdan 2008 yılında ayrı bir tüzel kişiliğe büründürülmüş ve 2009 yılında gerçekleşen yerel seçimlerle belediye teşkilatı fiili olarak varlık kazanmıştır. Yeni bir belediyenin kurulması ve yerleşim alanının yeni olması, kurucu belediye başkanını farklı yöntem arayışlarına yönelttiği anlaşılmaktadır. Bu bağlamda gerçekleştirilen çabalar kapsamında BYL 2011 yılında BB öncülüğünde kurulmuş, 2014 yılında aktif faaliyete başlamıştır. BYL kapsamında belirlenen odak alanlarıyla, yerleşim alanının teknoloji aracılığıyla iyileştirilmesine ve yine teknoloji aracılığıyla kentin ekonomisine katkı sağlamasına önem verilmektedir. Bu bağlamda BYL imkânları, girişimci adaylarına ve küçük işletmelere sunulmaktadır. Diğer taraftan BYL bünyesinde farklı taraflar yer almakla birlikte, özellikle farklı düzeylerde (lise, üniversite gibi) öğretmen/öğretim üyesi ve öğrencilerin varlığı dikkat çekmektedir. Gerçekleştirilen eğitim ve atölye çalışmalarında öğretmen/öğretim üyesi ve öğrencilerin katılımı öne çıkmaktadır. Bu özellikleriyle BYL, ortaya çıkışı, yapısı ve işleyişi açısından büyük oranda ilgili literatürle örtüşmektedir.

İfade edilenler çerçevesinde, çeşitli açılardan sorunlu alanları bulunmakla birlikte, Türkiye açısında BYL, YL oluşumunun önemli bir örneğini teşkil etmektedir. Diğer YL'lerle birlikte BYL pratiğinin olumlu-olumsuz, tüm yönleriyle dikkate alınarak incelenmesi dikkate değer bulunmaktadır. Buradan hareketle diğer kentlerde de benzer oluşumların ortaya çıkması önemli katkılar sağlayacaktır. Bu platformlar aracılığıyla, vatandaşların ve diğer tarafların katılımı sağlanarak, kamusal açıdan yenilik geliştirme sürecinde firmaların, belediye ile iş ilişkilerinde tekelci konumlarının zayıflamasına yol açacağına dikkat çekilmektedir. 
BYL oluşumuna yönelik gerçekleştirilecek sonraki araştırmalarda şu hususlar üzerinde durulabilir;

- Uzun vadeli değerlendirmeler ve karşılaştırmalı araştırmaların yapılması, normatif odaklı araştırmaların yapılması (Marvin vd., 2018: 10),

- Ekonomik etkisini ölçmeye yönelik çalışmaların yapılması (Ballon vd., 2018; Rodrigues \& Franco, 2018),

- Hukuksal açıdan incelenmesi,

- Farklı aktörler arasında iş birliğinin nasıl sağlandığının incelenmesi,

- Kullanıcı katılımının sağlanmasında dijital platformların nasıl bir rol üstlendiğinin incelenmesi,

- Ne düzeyde kamusal faydanın ortaya çıktığının incelenmesi,

- Detayda özel sektörün üstlendiği rollerin ne olduğunun incelenmesi,

- Geliştirilen yeniliklerin kamusal açıdan etkisinin ne olduğunun incelenmesi,

- Farklı tarafların katılımını sınırlandıran gerekçelerin ne olduğunun incelenmesi gibi.

\section{Kaynakça}

Abeysinghe, Y. N. (2016). Contribution of living labs for territorial development and innovation (Yayınlanmamış Yüksek Lisans Tezi). Tallinn University of Technology School of Information Technologies Department of Software Science, Erişim Tarihi: 10. 04. 2019, https://digi.lib.ttu. ee/i/file.php?DLID=7963\&t=1.

Almirall,E., \& Wareham, J. (2011). Living labs: Arbiters of mid and ground-level innovation. Technology Analysis \& Strategic Management, 23 (1), 87-102.

Angelini, L., Carrino, S., Khaled, O. A., Riva-Mossman, S., \& Mugellini, E. (2016). Senior living lab: An ecological approach to foster social innovation in an ageing society. Future Internet, 8 (50), 1-19.

Baccarne, B., Mechant, P., Schuurman, D., Colpaert, P., \& De Marez, L. (2014b). Urban socio-technical innovations with and by citizens. Interdisciplinary Studies Journal, 3 (4), 143-156.

Bakker, F. C., Mensen, M., Harps-Timmermann, A., \& Smits, C. (2017). An interdisciplinary community lab to facilitate citizen's participation and health: An exploratory study in developing lab tools for research, Education and Practice in Nursing, Social Work and Gerontology, Research Day Conference proceedings, 21-29, Erişim Tarihi: 20. 04. 2019, https://issuu.com/enoll/docs/ olld_2017_conference_proceedings_.

Ballon,P.,Hoed, M. V., \& Schuurman, D. (2018).The efectiveness of involving users in digital innovation: measuring the impact of living labs. Telematics and Informatics, 35 (5), 1201-1214.

Başakşehir Living Lab (2019). Hakkımızda, Erişim Tarihi: 29.04.2019, http://basaksehir-livinglab.com/ BLL/hakkimizda/.

Başakşehir Living Lab (2019b). Başakşehir living lab ekosistemi, Erişim Tarihi: 25.04.2019, . http:// basaksehir-livinglab.com/BLL/ekosistem/.

Başakşehir Living Lab (2019c). Başakşehir living lab e-bülten (57 nolu e-bülten, Şubat), Erişim Tarihi: 30.05.2019, https://basaksehir-livinglab.com/BLL/wp-content/uploads/2019/02/bultensayi57. html. 
Bifulco, F., Tregua, M., \& Amitrano, C. C. (2017). Co-Governing smart cities through living labs. Top evidences from EU. Transylvanian Review of Administrative Sciences, 50, 21-37.

Brask, M. (2015). The Role of urban living labs in fostering sustainable cities- Insights from Sweden (Yayınlanmamış Yüksek Lisans Tezi). Environmental Science Applied Climate Change Strategies Lund University, Erişim Tarihi: 10. 04. 2019, https://lup.lub.lu.se/student-papers/search/ publication/7368853.

Bulkeley, H., Coenen, L., Frantzeskaki, N., Hartmann, C., Kronsell, A., Mai, L., Marvin, S., McCormick, K., vanSteenbergen, F., \& Palgan, Y. V. (2016). Urban living labs: Governing urban sustainability transitions. Current Opinion in Environmental Sustainability, 22, 13-17.

Canzler, W., Engels, F., Rogge, J. C., \& Simon, D. (2017). From "living lab" to strategic action field: Bringing Together energy, mobility, and information technology in Germany. Energy Research\&Social Science, 27, 25-35.

Cardullo, P., Kitchin, R., \& DiFeliciantonio, C. (2018). Living labs and vacancy in the neoliberal city. Cities, 73, 44-50.

Casciola, L. C. (2016). Increasing diverses take holderin clusion in an urban living lab: An experiment in design activism (Yayınlanmamış Yüksek Lisans Tezi). Aalborg UniversityCopenhagen.

Coenen, T., van der Graaf, S., \& Walravens, N. (2014). Firing up th ecity - a smart city living lab methodology. Interdisciplinary Studies Journal, 3 (4), 1-11.

Cosgrave, E., Arbuthnot, K., \& Tryfonas, T. (2013). Living labs, innovation districts and information market places: A systems approach for smart cities. Procedia Computer Science, 16, 668-677.

Curtis, S. (2015). An investigation of living labs for sustainability reflections on the living lab methodology, Applied Research in Sustainable Consumption and Production (ARSCP) Master of Science in Environmental Management and Policy Lund, Sweden.

Dameri, R. P. (2013). Searching for smart city definition: A comprehensiveproposal. International Journal of Computers \& Technology, 11 (5), 2544-2551.

Evans, J., Bulkeley, H., Voytenko, Y., McCormick, K., \& Curtis, S. (2018). Urban Living Labs and the Politics of Sustainability. In K.Ward, A. E.G. Jonas, B. Miller, D. Wilson (Eds.), The Routledge handbook on spaces of urban politics (pp. 416-425). New York: Routledge.

Folstad, A. (2008). Living labs for innovation and development of information and communication technology: A literature review. The Electronic Journalfor Virtual Organizationsand Networks, 10,99-131.

Folstad, A.\& Karahasanović, A. (2015). A guideto online applications for user involvement in living lab innovation. Information Resources Management Association, Economics: Concepts, Methodologies, Tools, and Applications (IGI Global), 3, 426-444.

Franz, Y. (2015). Designing social living labs in urban research. Info, 17(4), 53-66.

Gasco, M. (2017). Living labs: Implementing open innovation in the public sector. Government Information Quarterly, 34, 90-98.

Graczyk, P. (2015). Embedding a living lab approach at the University of Edinburgh. Department for Social Responsibility and Sustainability, Erişim Tarihi: 20. 04. 2019, https://www.ed.ac.uk/files/ atoms/files/embedding_a_living_lab_approach_at_the_university_of_edinburgh.pdf.

Habibipour, A. (2018). Living lab research: A state-of-the-art review and steps towards a research agenda. Erişim Tarihi 20.04. 2019, http://www.diva-portal.org/smash/record.jsf?pid=diva2\%3A1239574 \&dswid $=-3362$.

Herselman, M., Marais, M., \& Pitse-Boshomane, M. (2010). Applying living lab methodology to enhance skills in innovation. eSkillsSummit 2010 Proceedings, 1-7. 
Hossain, M., Leminen, S., \& Westerlund, M. (2019). A systematic review of living lab literature. Journal of CleanerProduction, 213, 976-988.

Juujärvi, S., \& Pesso, K. (2013). Actorroles in an urban living lab: What can we learn from Suurpelto, Finland?. Technology Innovation Management Review, 3 (11), 22-27.

Katzy, B.R., \& Bücker, C. (2015). The organization of living labs: Coordinating activities for regional innovation. Technology Innovation Management Review, 5 (9), 23-28.

Kviselius, N. Z., Ozan, H., Edenius, M., \& Andersson, P. ( ? ): The evolution of living labs - Propositions for Improved Design and Further Research. 842-856, Erişim Tarihi: 22. 04. 2019, https://www. researchgate.net/publication/228653862_The_Evolution_of_Living_Labs-Propositions_for_ Improved_Design_and_Further_Research.

Leminen, S., \& Westerlund, M. (2015). Incremental and radical service innovation in living labs. In MehdiKhosrow-Pour (ChiefEds.), Economics: Concepts, methodologies, Tools, and Applications (pp. 445-459), United States:IGI Global.

Leminen, S. (2015). Living labs as ope nınnovation networks: Networks, roles and innovation outcomes (Doctoral Dissertations). Aalto University, School of Science Department of Industrial Engineering and Management, Erişim Tarihi 16. 04. 2019, https://aaltodoc.aalto.fi/handle/123456789/17899.

Leminen, S., Nyström, A.-G., Westerlund, M., \& Kortelainen, M. J. (2016). The effect of network structure on radical innovation in living labs. Journal of Business \& Industrial Marketing, 31 (6), 743-757.

Lin, W. Y., Lin, C. T., Wang, Y. H., \& Chen, R. T. (2012). The transformation of users in living lab construction: The case of eco-city living lab. International Journal of Automationand Smart Technology (AUSMT), 2 (3), 231-240.

Marvin, S., Bulkeley, H., Mai, L., McCormick, K., \& Palgan, Y. V. (Eds.) (2018). Urban living labs: Experimenting with city futures (pp. 1-17), New York:Routledge.

Menny, M. (2016). Users as co-creators? an analysis of user involvement in urban living labs. Thesis for the Fulfilment of the Master of Science in Environmental Management and Policy Lund, Sweden, Erişim Tarihi 10.04. 2019, https://lup.lub.lu.se/student-papers/search/publication/8893215.

Menny, M., Palgan, Y. V., \& McCormick, Kes (2018). Urban living labs and the role of users in co-creat, GAIA 27/S1, 68-77.

McLoughlin, S., Maccani, G., Prendergast, D., \& Donnellan, B. (2018). Living labs: A bibliometric analysis. Hawaii International Conference on SystemSciences (HICSS), Hawaii.

Mengual, M. P., Jonas, J. M., Schmitt-Rüth, S., \& Danzinger, F. (2018). Tools for collaborating and interacting in living labs - An exploratory case study on JOSEPHS. ServDes2018, Erişim Tarihi: 14. 04. 2019, http://www.servdes.org/wp/wp-content/uploads/2018/07/25.pdf.

Nesti, G. (2017). Co-production for Innovation: The Urban living lab experience, policy and society. Policy and Society, 37 (3), 1-16.

Öztürk, A. İ. (2019). Başlangıçtan Bugüne İstanbul'un Belediyeleri. İstanbul: İdeal Kültür Yayıncılık.

Paskaleva, K. A. (2011). Thesmartcity: A nex us for open innovation?. Intelligent Buildings International, $3(3), 153-171$.

Puerari, E., de Koning, J. I. J. C., vonWirth, T., Karré, P. M., Mulder, I. J., \& Loorbach, D. A. (2018). Co-creation dynamics in urban livinglabs. Sustainability, 10, 1-18.

Rodrigues, M., \& Franco, M. (2018). Importance of livinglabs in urban entrepreneurship: A Portuguesecasestudy. Journal of CleanerProduction, 180, 780-789.

Sadioğlu, U., \& Erdinçler, R. E. (2018). Akıllı kentler ve Türk kentleri için politika önerileri. İçinde A. Mengi ve D. İşçioğlu (Ed.), Küreselleşme sürecinde yerel hizmet yerel siyaset (s.81-101), Ankara: Ankara Üniversitesi. 
Schuurman, D., De Marez, L., \& Ballon, P. (2013). Open innovation processes in living lab innovation systems: Insights from the LeYLab. Technology Innovation Management Review, 3 (11), 28-36.

Schuurman, D., De Marez, L., \& Ballon, P. (2016). The impact of living lab methodology on open innovation contributions ando utcomes. Technology Innovation Management Review, 6 (1), 7-16.

Scholl, C., \& Kemp, R. (2016). City labs as vehicles for innovation in urban planning processes. Urban Planning, 1 (4), 89-102.

Sharp, D., \& Salter, R. (2017). Direct impacts of an urban living lab from the participants' perspective: Livewell Yarra. Sustainability, 9, 1-15.

Smas, L., Schmitt, P., Perjo, L., \& Tunström, M. (2016). Positioning urban labs - a New Form of Smart Governance?. Proceedings of 21 st International Conference on Urban Planning, Regional Development and Information Society, 919-923, Erişim Tarihi: 01. 05. 2019.https://repository. corp.at $/ 179 /$.

Steen, K., \& van Bueren, E. (2017). Urban living labs: A living lab way of working. Erişim Tarihi 20. 04. 2019, https://amsterdamsmartcity.com/projects/a-living-lab-way-of-working.

Ståhlbröst, A., Bergvall-Kåreborn, B., \& Eriksson, C. I. (2015). Stakeholders in smart city living lab processes. Twenty-first Americas Conference on Information Systems, Puerto Rico, Erişim Tarihi: 26. 04. 2019, https://www.diva-portal.org/smash/get/diva2:1006027/FULLTEXT01.pdf.

Ståhlbröst, A. (2013). A living lab as a service: Creating value formicro-enterprisest hrough collaboration and innovation. Technology Innovation Management Review, 3, 11, 37-42.

Westerlund, M., Leminen, S., \& Rajahonka, M. (2018). A topic modelling analysis of living labs research. Technology Innovation Management Review, 8 (7), 40-51. 